\title{
Using Library Funds to Support Open Access Publishing Through Crowdfunding: Going Beyond Article Processing Charges
}

\author{
Thomas L. Reinsfelder MSLS, PhD \\ Associate Librarian \\ Penn State University Libraries - Mont Alto \\ tlr15@psu.edu \\ Caitlin Pike MLS, AHIP \\ Nursing and Medical Humanities Liaison Librarian \\ Indiana University-Purdue University Indianapolis \\ caiapike@iupui.edu
}

\begin{abstract}
:
Publishers commonly use Article Processing Charges (APCs) to fund open access publications, and some libraries and institutions help local authors pay these costs. However, this strategy is expensive and can usually only address one article at a time. A number of relatively new publishing initiatives rely on a crowdfunding model and allow many libraries to share the cost of open access, often at a fraction of the cost of APCs. This article highlights several alternative publishing projects to help librarians think further about how library funds could be used to support open access.
\end{abstract}

This the author's version of an article published in Collection Management.

Reinsfelder, T.L. \& Pike, C.A. (2018). Using library funds to support open access publishing through crowdfunding: Going beyond article processing charges. Collection Management, 48(2). doi:10.1080/01462679.2017.1415826

Collection Management is available online at: http://www.tandfonline.com/loi/wcol20 
It is clear that just because an article or book may be free to read online, it is certainly not free to produce. Someone is still paying to support the work being done. While a significant number of academic libraries currently administer special funds to pay some of these costs on behalf of individual authors, librarians should also seek out other options to support open access publishing with the goal of achieving the best possible return on investment. This paper explores some currently available alternatives, some new and innovative publishing models using Crowdfunded scholarly publishing. We explore how much open access to scholarship a library could support if a hypothetical $\$ 25,000$ were directed toward innovative publishing models and projects.

\section{Libraries and Open Access Publishers}

Scholarly publishers have many ways to cover the costs of making content freely available to readers (Crow, 2009). One of the most well-known methods uses article processing charges (APCs). These APCs, also known as author publication fees, charge authors an upfront cost to make the article available to readers at no cost. In recent years, many libraries and institutions established special funds to help pay the article processing charges required to publish in some open access journals. These funds are a step in the right direction as authors, librarians, and institutions demonstrate a desire to support the open access movement - but they can be expensive, and can only address one article at a time. The experience at Johns Hopkins University, where an open access fund was discontinued, demonstrates that this model can be difficult to sustain as the demand from authors in this case quickly surpassed available funds each year between 2012 and 2015 (Sinn, Woodson, and Cyzyk 2017) 
SPEC Kit 353, published by the Association of Research Libraries (ARL) in late 2016, provides an in-depth look at the state of library funds dedicated to supporting open access article processing charges (McMillan, O’Brien, and Young 2016). This report indicates that a significant number of ARL libraries have started or continue to offer funds to cover these costs. However, according to the report, the majority of responding libraries (62\%) either discontinued their APC fund or have no plans to start one, with the most common reason being cited as lack of funding.

\section{An Emerging Model}

The relatively new OA2020 initiative, which builds on the Berlin Declaration on Open Access to Knowledge in the Sciences and Humanities, is encouraging libraries to commit to a greater merging of traditional subscription budgets with newer open access publication funds "to support non-APC-based OA-publishing models, and to support local and regional OA publishers and journals” in order to hasten the transition away from subscriptions and toward open access (Open Access 2020). Peter Suber, one of the most prominent forces in the open access movement observed in a 2015 interview that there is already enough money in the academic and scholarly ecosystem to support the current volume of scholarship (LaGuardia 2015). Suber went on to remark that we don't need more money, it just needs to be redirected in a more efficient way to both further open access publishing and reduce costs.

Universities have always paid to support the creation of scholarly content by funding researcher salaries, and libraries have always paid to support the publication and distribution of scholarly content, usually through collection funds. However, the special funds created to support open access through APCs are often separately administered and typically represent an additional cost to the library. But do they have to remain separate? Could libraries effectively 
combine and strategically deploy traditional collection funds along with newer funds meant to further open access? While most discussions have centered on journals, there is also plenty of room for experimentation around open access e-books.

\section{Crowdfunding, Libraries, \& Open Access}

Grabowsky's work on open access and collection management calls attention to several innovative efforts to "crowd source" open access such as $\mathrm{SCOAP}^{3}$ and Knowledge Unlatched, which are described further below (2015). With crowdsourcing, also called crowdfunding, projects are proposed with a stated monetary goal. Once enough financial pledges are received, and the target price is met, the project moves forward toward completion.

Even if many people are familiar with crowdfunding through popular platforms like KickStarter or GoFundMe, the idea of using this method of fundraising for open access scholarly publishing is still quite new. The core concept centers around the assumption that when something is valued people (or organizations) will pay to support it through donations or other contributions. Some efforts exist around crowdfunding for scholars, but most focus on the research endeavors of an individual or on other projects of a relatively small scale (Adema 2011; Cadogan 2014). However, donations from individuals do not seem to be a viable and sustainable solution for open access academic journals or other large scale scholarly publication projects (Reinsfelder 2015). Libraries, universities, and other research organizations and partners will need to lead the way.

Several open access advocates have talked about the idea of crowdsourcing library funds as a way to support open access in addition to, or instead of, APCs. In 2014 Martin Paul Eve wrote: 
the backlash against article and book processing charges has triggered investigations into a range of new models that seek to provide gold open access in a sustainable fashion without any author-facing charges. Under such models many libraries each pay a small amount in order to sustain a large-scale infrastructure (61).

Using similar logic, Look \& Pinter in 2010 described the idea that led to the current Knowledge Unlatched initiative in this way:

if, say 1,000 libraries paid into a fund that "bought" the non-commercial open access rights to a book that carried, for the sake of the arithmetic, a "getting to first copy" cost of $\$ 10,000$, then each library would contribute $\$ 10.00$. The average monograph today costs approximately $\$ 80.00$. This would not only get libraries eight times as many titles online, it would be truly contributing to making knowledge accessible globally (95).

While this sounds promising, some librarians may be skeptical due to concerns about shifting funds away from current journal subscriptions or non-participating libraries that would not contribute to the overall cost, thereby increasing the share to be paid by others (Grabowsky 2015, 20).

\section{Article Processing Charges vs. Crowdfunded Scholarly Projects: Which is Better?}

Librarians and collection managers clearly have many different ways to acquire and pay for content, but the question regarding the best use of funds remains. In SPEC Kit 353 when speaking about how libraries set up funds to pay for article processing charges, one survey respondent noted that "the $\$ 25,000$ allocation could be spent more effectively on other initiatives, including memberships and pledges with innovative open access journal and 
monograph publishers, and library publishing cooperatives” (McMillan, O’Brien, and Young 2016, 5).

The following pages will explore how much open access to scholarship a library could support if a hypothetical \$25,000 were directed toward some new and innovative publishing models and projects. This amount is slightly lower than the reported median APC fund amount of \$40,000 (McMillan, O’Brien, and Young 2016, 3). For comparison and for perspective Table 1 displays how \$25,000 could be spent on article processing charges (APCs) and traditional library books and journal purchases.

\begin{tabular}{|l|l|l|}
\hline \multicolumn{2}{|c|}{$\begin{array}{c}\text { What a Library Could Purchase for \$25,000 } \\
\text { (Article Processing Charges, Books, \& Subscription Based Journals) }\end{array}$} \\
\hline $\begin{array}{l}\text { OA Article Processing } \\
\text { Charges }\end{array}$ & $\begin{array}{l}12.5 \text { open access articles } \\
\text { Library funds typically pay about } \\
\text { \$2,000 per open access article } \\
\text { (McMillan, O’Brien, and Young } \\
\text { 2016, 5). }\end{array}$ \\
\hline Book Purchases & $\begin{array}{l}\text { 269 books } \\
\text { Journal Subscriptions }\end{array}$ & $\begin{array}{l}\text { The average list price for a new } \\
\text { academic book is \$92.73 USD (YBP } \\
\text { Library Services 2017). }\end{array}$ \\
\hline & $\begin{array}{l}\text { 25 one year } \\
\text { subscriptions to a US } \\
\text { periodical } \\
\text { OR } \\
16 \text { one year } \\
\text { subscriptions to a Non- } \\
\text { US periodical }\end{array}$ & $\begin{array}{l}\text { The average subscription cost for a } \\
\text { journal is \$965 for US titles and } \\
\text { \$1,503 for titles outside of the US } \\
\text { (Bosch and Henderson 2017). }\end{array}$ \\
\hline
\end{tabular}




\section{Crowdfunded Scholarly Publishing Projects}

Alternatively, that same $\$ 25,000$ could be spent on some of the existing and emerging publishing initiatives that use a crowdfunding or sponsorship model. In most cases, libraries or organizations contribute a set amount of money to support a specific open access project or publisher. Once a predetermined target is reached the publisher agrees to distribute the content to readers for free and without charging additional fees to authors or readers. Ten publishing projects are profiled below and consider what it would look like if $\$ 25,000$ were spent on each. First we offer a summary (Table 2) with more detailed profiles of each project provided in the text below. Many initiatives are based on recurring annual fees or memberships, while some such as Unglue.it, Reveal Digital, and Knowledge Unlatched allow libraries to contribute to one title, project, or collection at a time. When it comes to long term digital preservation, a variety of strategies are used. Knowledge Unlatched, Open Book Publishers, and UC Press Luminos use the Portico digital archiving service. Open Library of the Humanities, Unglue.it, and Reveal Digital use either CLOCKSS or LOCKSS. For others, the long term preservation plans are less clear. 


\begin{tabular}{|c|c|c|}
\hline \multicolumn{3}{|c|}{$\begin{array}{c}\text { TABLE } 2 \\
\text { Summary of Innovative Open Access Scholarly Publishing Projects }\end{array}$} \\
\hline & $\$ 25,000$ Could Fund & Cost Details \\
\hline Knowledge Unlatched & $\begin{array}{l}471 \text { new books } \\
\text { OR } \\
1,886 \text { backlist books } \\
\text { OR } \\
10 \text { years of support for the } \\
\text { open access journal } \\
\text { collection. Currently } 21 \text { titles }\end{array}$ & $\begin{array}{l}\$ 53 \text { per new open access } \\
\text { book } \\
\text { OR } \\
\$ 13.25 \text { per backlist book } \\
\text { made open access } \\
\text { OR } \\
\$ 2,333 \text { per year for the } \\
\text { journal collection } \\
\text { (\$111 per journal title per } \\
\text { year) }\end{array}$ \\
\hline $\mathrm{SCOAP}^{3}$ & $\begin{array}{l}\text { Between } 1 \text { and } 25 \text { years of } \\
\text { SCOAP }^{3} \text { membership } \\
\text { (depends on library size and } \\
\text { past subscription patterns) }\end{array}$ & Cost varies by institution \\
\hline arXiv & $\begin{array}{l}\text { Institutional membership at } \\
\text { the highest tier for } 8 \text { years }\end{array}$ & $\begin{array}{l}\text { Institutional membership } \\
\$ 1,500-\$ 3,000 \text { per year }\end{array}$ \\
\hline $\begin{array}{l}\text { Open Library of the } \\
\text { Humanities }\end{array}$ & $\begin{array}{l}14 \text { open access journals for } \\
15 \text { years, at the highest } \\
\text { contribution rate }\end{array}$ & $\begin{array}{l}\text { Annual fee based on FTE. } \\
\$ 1,600 \text { for the largest } \\
\text { institutions }\end{array}$ \\
\hline Unglue.it & $\begin{array}{l}\text { Depends on cost of individual } \\
\text { titles }\end{array}$ & Cost varies by title \\
\hline Reveal Digital & $\begin{array}{l}\text { Several digitization projects } \\
\text { of newspaper content }\end{array}$ & $\begin{array}{l}\text { Cost varies by project } \\
\text { institution type }\end{array}$ \\
\hline Lever Initiative / Lever Press & $\begin{array}{l}\text { 3-12 years of funding to } \\
\text { support publication of open } \\
\text { access e-books }\end{array}$ & $\begin{array}{l}\$ 2,000-\$ 8,000 \text { per year } \\
\text { depending on collection } \\
\text { budget }\end{array}$ \\
\hline Open Book Publishers & $\begin{array}{l}50 \text { years in the library } \\
\text { membership program }\end{array}$ & $\begin{array}{l}\text { \$500 annual fee for library } \\
\text { membership }\end{array}$ \\
\hline UC Press Luminos & $\begin{array}{l}\text { 1-25 years of membership } \\
\text { depending level }\end{array}$ & $\begin{array}{l}\text { Libraries can join at one of } \\
\text { four membership levels, from } \\
\$ 1,000 \text { to } \$ 20,000^{+}\end{array}$ \\
\hline $\begin{array}{l}\text { Open Access Monograph } \\
\text { Publishing Initiative }\end{array}$ & $\begin{array}{l}1.66 \text { open access monograph } \\
\text { publishing grants. }\end{array}$ & $\begin{array}{l}\$ 15,000 \text { for each publishing } \\
\text { grant to create an open access } \\
\text { e-book. }\end{array}$ \\
\hline
\end{tabular}




\section{Knowledge Unlatched - knowledqeunlatched.org}

Knowledge Unlatched began in 2012 with the goal of bringing libraries and publishers together to produce open access scholarly books, primarily in the social sciences and humanities, but is now also beginning to work with some STEM titles. According to the organization's website, publishers first submit titles they would like to make open access and a selection committee approves the titles for a Knowledge Unlatched collection. Libraries are then invited to select groups of titles or packages to pledge their support. When enough pledges have been received the titles are produced and published open access. Once completed, freely downloadable PDF and EPUB files are made available online by OAPEN and HathiTrust. Knowledge Unlatched has also partnered with OCLC and a variety of other organizations. By late summer 2017 Knowledge Unlatched has worked with 70 publishers and over 450 libraries to produce approximately 500 open access e-books and has plans to begin working with journal publishers as well.

\section{Cost to Support:}

Book Collection: Full pledge for 2017 (343 books), \$10,547 per library, average cost \$53 per new book (151); \$13.25 per backlist book (192).

Journal Collection: Full pledge for 2017 (21 journals, to be published open access for an initial three year period beginning in 2018): \$2,333 per library per year. Average price per title per year, \$111.00. After three years, Knowledge Unlatched will reevaluate the arrangement with publishers and libraries may be asked to pledge further support to continue the program. Differential (discounted) pricing is available based on Carnegie or JISC classification.

\section{\$25,000 spent at Knowledge Unlatched could fund:}


- 471 new open access books (at the current rate of $\$ 53$ per new book) OR

- 1,886 backlist books (at the current rate of $\$ 13.25$ per backlist book) OR

- 10 years of support for the open access journal collection. Currently 21 titles at the rate of $\$ 2,333$ per year - or $\$ 111$ per title per year.

\section{$\underline{\text { SCOAP }} \underline{3}$ Sponsoring Consortium for Open Access Publishing in Particle Physics - scoap3.org}

SCOAP ${ }^{3}$ launched in 2014, has formed partnerships with CERN, the European Organization for Nuclear Research, the American Physical Society (APS), and over 3,000 libraries, key funding agencies, and research centers in 44 countries and 3 intergovernmental organizations. In the United States, LYRASIS administers SCOAP ${ }^{3}$ for CERN. The focus here is on scholarly journals in the fields of high energy physics and particle physics. SCOAP ${ }^{3}$ covers 11 journals and over 15,000 open access articles. Approximately 90\% of the annual high energy physics article literature is expected to be included in SCOAP ${ }^{3}$ by 2018. In this model, participating libraries redirect money previously used for subscribing to $\mathrm{SCOAP}^{3}$ journals into a common fund, from which the publication costs are paid. Subscription fees are reduced for the journals that remain part subscription and part OA. Subscription fees are eliminated for the journals that are completely OA. Publishers are not being compensated for the same article with both subscription dollars and SCOAP ${ }^{3}$ dollars. This is similar to the APC funding model, but here publishers are supported collectively among many libraries/funders. Some of the SCOAP 3 journals are included in their entirety, and some journals have only part of their contents in the $\mathrm{SCOAP}^{3}$ program (i.e., just those articles relevant to the sub-discipline of high energy physics).

\section{Cost to Support:}

Each partner library is asked to redirect the amount it previously spent on subscriptions to the journals included. The SCOAP ${ }^{3}$ model is one of offset, i.e., swap-out. Whatever amount the 
library was previously paying to the publisher for a subscription, now goes to $\mathrm{SCOAP}^{3}$, which pays the publisher. The biggest research libraries, with subscriptions to all the $\mathrm{SCOAP}^{3}$ journals, may be paying up to $\$ 20 \mathrm{~K}$ per year. The smallest libraries that may have historically subscribed to only one $\mathrm{SCOAP}^{3}$ journal now with partial content in $\mathrm{SCOAP}^{3}$, could be paying as little as $\$ 100$, though very few libraries are at either extreme (Ann Okerson and Celeste Feather, personal communication, 6/1/17).

\section{$\$ 25,000$ spent at SCOAP ${ }^{3}$ could fund:}

- Between 1 and 25 years of SCOAP ${ }^{3}$ membership (depending on library size and past subscription patterns).

\section{$\underline{\text { arXiv-arxiv.org }}$}

This is one of the longest running and most popular repositories of open access literature with approximately 1.3 million documents collected since 1991. arXiv continues to grow and contains articles and preprints primarily in the areas of physics, mathematics, computer science, quantitative biology, quantitative finance and statistics. Hosted by the Cornell University Library, arXiv receives base funding from Cornell University and the Simons Foundation, with member institutions pledging additional financial support. Each member institution pledges a five-year funding commitment to support arXiv. Cornell's goal is to raise at least $\$ 300,000$ per year through membership fees generated by approximately 208 institutions.

\section{Cost to Support:}

Based on institutional usage ranking, the annual fees are set in four tiers from $\$ 1,500$ $\$ 3,000$.

\section{\$25,000 spent at arXiv could fund:}

- An institutional membership at the highest tier for 8 years. 


\section{Open Library of the Humanities - openlibhums.org}

The Open Library of the Humanities (OLH) began in 2013 and publishes 14 peerreviewed journals, with preliminary plans to begin publishing open access books as well. The OLH is a not-for-profit UK organization and is funded through "library partnership subsidies" and is supported by an international consortium of libraries along with two grants from the Andrew W. Mellon Foundation. A base cost covers ongoing technological costs, staff costs, digital preservation, typesetting and other costs. When this is spread across institutions, the cost to each institution is just several dollars per open-access article. The economy of scale improves as more institutions join.

\section{Cost to Support:}

- FTE Less than 5,000; Annual Fee $\$ 534$

- FTE 5,000-9,000; \$900 Annual Fee

- FTE 10,000+; Annual Fee $\$ 1,600$

\section{\$25,000 spent at Open Library of the Humanities could fund:}

- 14 open access journals for 15 years, at the highest contribution rate.

\section{Unqlue.it - unqlue.it}

Unglue.it launched in 2011 and strives to provide open access to e-books in all disciplines through open crowd-funding with some additional options for libraries. Unglue.it makes books open access in three ways. First, authors can write an e-book and sell individually licensed copies. After a sales (funding) goal is met, a Creative Commons license is applied and the book is free to read and download from that point forward (known as Buy-to-Unglue). Second, an author can write an e-book and immediately apply a Creative Commons license, then ask readers for donations. Third, an author can set a funding goal. If and when enough pledges 
are received, the e-book will be created and shared with a Creative Commons license. As of August 2017 there are over 50 active campaigns to unglue various books.

\section{Cost to Support:}

Varies. "Libraries may:

- Purchase Buy-to-Unglue e-book licenses

- Allow library users to borrow buy-to-unglue e-books. "The library license gives download access to one library member at a time for 14 days each" (knowledgeunlatched.org)

- Allow library users to purchase buy-to-unglue e-books for the library

- Manage lists of unglued and public domain e-books for users" (Christou 2016)

\section{\$25,000 spent at Unglue.it could:}

- Contribute to making multiple books open access.

\section{$\underline{\text { Reveal Diqital - revealdiqital.com }}$}

Reveal Digital is somewhat unique and relatively new (2017) when compared to other initiatives. The emphasis here is on archival and historical collections and projects. Reveal Digital is advised by an executive committee composed of library leaders from across the United States. and uses library acquisition dollars to fund the development of open access digital collections through library crowdsourcing. First, libraries propose collections for digitization, then a cost recovery threshold is established and funding support is sought from interested libraries. When the funding target is met, the digitization project moves forward and content is made available online - open access. "Libraries that fund a collection will receive early access to the collection, free MARC records, COUNTER compliant usage reports and full support for mass text downloading” (Reveal Digital).

\section{Cost to Support:}

The cost for each project varies. If the funding target is surpassed, the cost per library is reduced. The "Independent Voices” newspaper collection contains complete runs of over 1,000 
titles and 750,000 pages. This project was supported by 116 libraries and is the first Reveal Digital project to be funded at $100 \%$. The funding tiers for this collection are listed below by library type and one-time payment.

- 2 yr colleges and smaller publics; $\$ 5,130$

- Bachelors; \$5,130

- $\quad$ Masters and large publics; $\$ 6,770$

- Other Doctorate; $\$ 10,250$

- ARLs; $\$ 20,500$

\section{\$25,000 spent at Reveal Digital could fund:}

- Several digitization projects for most libraries.

\section{The Lever Initiative and Lever Press - leverpress.org}

The Lever Initiative began in 2015, and focuses primarily on producing liberal arts ebooks. Curated by The Oberlin Group, an organization composed of several top-ranked U.S. liberal arts colleges, Lever Press creates open access e-books with no cost to authors or readers. This is accomplished through the use of institutional memberships. Supporting libraries are publicly recognized in all published titles and receive a 50\% discount on print titles. Lever Press aims to produce 60 new titles by the end of 2020 .

\section{Cost to Support:}

- Collection Budget <\$500k; Annual Cost \$2,000; Five-Year Cost $\$ 10,000$

- Collection Budget \$500k-\$750k; Annual Cost \$4,000; Five-Year Cost \$20,000

- Collection Budget \$750k-\$1.5 million; Annual Cost \$6,000; Five-Year Cost \$30,000

- Collection Budget >1.5 million; Annual Cost \$8,000; Five-Year Cost \$40,000

\section{\$25,000 spent at Lever Press could fund:}

- Three to twelve years of membership as a supporting library, depending on a library's collection budget.

\section{Open Book Publishers - openbookpublishers.com}


Open Book Publishers (OBP), established in 2008, is a multi-disciplinary e-book publisher that relies on the sales of ePub and print editions, donations, and a library membership program for funding. HTML and PDF versions of an e-book are offered for free, while print, and ePub versions are available for purchase. Donations are accepted from individuals, as well as institutions, and authors are not required to pay for publication. Members libraries that contribute financially receive digital editions of every title, MARC records, and discounts on print copies for the library as well as students and employees of the institution. OBP is affiliated with many organizations, including Library for All, the Directory of Open Access Books, and the Open Access Scholarly Publishers Association, among others. As of August 2017, OBP had 101 ebooks available on subjects in the humanities and social sciences.

\section{Cost to Support:}

The annual fee for library membership is \$500 per year.

\section{\$25,000 spent at Open Access Books could fund:}

- 50 years of membership

\section{$\underline{\text { UC Press Luminos - luminosoa.org }}$}

Luminos is a University of California supported venture that began in 2015 for e-books in the humanities and social sciences. Luminos e-books can be read for free in a web browser or downloaded in PDF or ePub format. Funded through a UC Press subsidy, along with author and institutional fees, print sales, and library memberships Luminos currently offers 34 e-books as of August 2017. According to their website, Luminos "believe[s] in sharing costs between all parties who benefit from publication - author, or institution, and libraries. In our model, no one entity carries the whole burden [of cost]." Authors are asked to contribute \$7,500 from their institution or other sources. In addition, libraries can contribute at one of four membership levels. 
Member libraries help support open access publishing and receive discounts on title publication fees for their faculty.

\section{Cost to Support by Membership Level:}

- $\$ 1,000-\$ 5,000 ; 10 \%$ Discount on publication fee for faculty

- $\$ 5,000-\$ 10,000 ; 15 \%$ Discount on publication fee for faculty; Can purchase 50 books at a $50 \%$ discount

- \$10,000-\$20,000; 20\% Discount on publication fee for faculty; Can purchase 50 books at a 50\% discount; Invitation for representative on advisory board

- $\$ 20,000+$; 30\% Discount on publication fee for faculty; Can purchase 50 books at a 50\% discount; Invitation for representative on advisory board

\section{\$25,000 spent at Luminos could fund:}

- 1 to 25 years of membership, depending on membership level.

\section{Open Access Monograph Publishing Initiative (OAMPI) -}

aaupnet.org/resources/for-authors-a-faculty/oa-monograph-initiative

A new joint initiative from the Association of American Universities (AAU), the Association of Research Libraries (ARL), and the Association of American University Presses (AAUP), the Open Access Monograph Publishing Initiative (OAMPI) is a multi-disciplinary effort to create open access e-books. Institutions, including Penn State, Emory, Michigan State, and Indiana University, have agreed to "provide a baseline university publishing grant of $\$ 15,000$ to support the publication of an open access, digital monograph; set a target of awarding at least three publishing grants per year; and commit to participating in this initiative for five years" (Association of American University Presses). This initiative has just begun in early 2017, but could lead to the publication of up to 900 open access e-books in five years if 60 AAUP member presses participate at the rate of three open access books per year.

\section{Cost to Support:}

Three $\$ 15,000$ publishing grants per year $=\$ 45,000$ x 5 years $=\$ 225,000$. 


\section{\$25,000 spent at OAMPI could fund:}

- The creation of 1.66 open access e-books.

\section{Conclusion}

The projects above are all examples of where libraries could redirect money spent on traditional book and journal purchases, and combine it with funds from other libraries to provide greater access to scholarly books, articles, and other materials. After analyzing these open access initiatives and funding models it becomes clear that librarians must think carefully about the money currently being spent on APCs. At current rates, these charges are a much more expensive way to pursue open access than some of the relatively new and emerging alternatives. For example, the same amount of money needed to fund 12.5 article processing charges for articles in OA journals could support 471 new OA books at Knowledge Unlatched, or offer several years of financial support to projects like arXiv, Lever Press, SCOAP ${ }^{3}$, or UC Press Luminos.

In our opinion, it is not realistic to believe that in the future all professional and scholarly literature will be open access, but there is still plenty of room for growth and much more progress can be made. We recommend that librarians continue to seek out and support new publishing models to further improve academic libraries, open access, and the sustainability of scholarly research. Librarians will likely not want to put all available money into only one project, but instead choose to evaluate and fund those that best align with existing collection development priorities. Going forward, an additional challenge will be identifying which projects have the potential to be successful over the long term. Not every new publishing project will survive the test of time, meaning there will be some risk and uncertainty involved. Some libraries have already made great strides and are actively contributing to many of the projects profiled 
here, along with others, and that is an encouraging sign, but in order to bring about significant and lasting change participation from all libraries will be needed.

Some readers may wonder how libraries with already stretched budgets can commit additional funds to support these new projects. In response, we challenge all librarians to reconsider the observation noted earlier where Peter Suber explained that "money already spent on journals by academic libraries is more than enough to pay for high-quality OA journals in every scholarly niche. We don't need new money, we just need to redirect the money we already spend” (LaGuardia 2015).

\section{REFERENCES}

Adema, Janneke. “On Crowdfunding Open Access Scholarly Books.” Accessed October 27, 2017. http://openreflections.wordpress.com/2011/08/03/on-crowd-funding-open-accessscholarly-books

Association of American University Presses. "AAU, ARL, AAUP to Launch Open Access Monograph Publishing Initiative." Accessed October 27, 2017 http://www.aaupnet.org/resources/for-authors-a-faculty/oa-monograph-initiative

Bosch, Stephen and Kittie Henderson. 2017. "New World, Same Model: Periodicals Price Survey 2017.” Library Journal, 142 (7): 40-45. Accessed October 27, 2017. http://lj.libraryjournal.com/2017/04/publishing/new-world-same-model-periodicals-pricesurvey-2017

Cadogan, Dawn. 2014. "Funding for Research? Look No Further Than the Crowd: Crowdfunding Resources for Academia.” College \& Research Libraries News 75 (5): 268-271. doi:10.5860/crln.75.5.9128

Christou, Corilee. 2016. “Unglue.it Builds a Supply Chain of Free E-books.” Accessed October 27, 2017. http://newsbreaks.infotoday.com/NewsBreaks/Unglueit-Builds-a-SupplyChain-for-Free-E-books-110480.asp

Crow, Raym. 2009. “Income Models for Open Access: An Overview of Current Practice.” Scholarly Publishing \& Academic Resources Coalition, Washington DC. Accessed October 27, 2017. http://sparcopen.org/wpcontent/uploads/2016/01/incomemodels_v1.pdf 
Eve, Martin Paul. 2014. Open Access and the Humanities: Contexts, Controversies and the Future. Cambridge: Cambridge University Press.

Grabowsky, Adelia. 2015. “The Impact of Open Access on Collection Management.” Virginia Libraries 61 (1):17-22. doi:10.21061/valib.v61i1.1325

LaGuardia, Cheryl. 2015. “An Interview with Peter Suber on Open Access: Not Dead Yet.” Library Journal, September 30, 2015. Accessed October 27, 2017. http://lj.libraryjournal.com/2015/09/opinion/not-dead-yet/an-interview-with-peter-suberon-open-access-not-dead-yet

Look, Hugh and Frances Pinter. 2010. "Open Access and Humanities and Social Science Monograph Publishing." New Review Of Academic Librarianship 16 (S1): 95. doi:10.1080/13614533.2010.512244

McMillan, Gail, Leslie O’Brien, and Philip Young. 2016. Funding Article Processing Charges. Washington DC: Association of Research Libraries. Accessed October 27, 2017. http://publications.arl.org/Funding-Article-Processing-Charges-SPEC-Kit-353

Open Access 2020. OA2020 Roadmap. Accessed August 22, 2017. https://oa2020.org/roadmap

Reinsfelder, Thomas. 2015. "Donations as a Source of Income for Open Access Journals: An Option to Consider?” The Journal of Electronic Publishing 18 (3). doi:10.3998/3336451.0018.307

Reveal Digital. “How it Works.” Accessed October 27, 2017. http://revealdigital.com/how-itworks

Sinn, Robin N., Sue M. Woodson, and Marc Cyzyk. 2017. “The Johns Hopkins Libraries Open Access Promotion Fund.” College \& Research Libraries News 78 (1):32-35, doi: 10.5860/crln.78.1.9605

YBP Library Services. 2017 Annual Book Price Update. Accessed October 27, 2017. http://www.gobi3.com/StaticContent/GOBIContent/YBP/Private/Help/Pages/bookpriceu pdate.html 